\title{
Medicinal uses of Cannabis sp.
}

\author{
Usos medicinais de Cannabis sp. \\ Usos medicinales de Cannabis sp.
}

Received: 06/07/2021 | Reviewed: 06/13/2021 | Accept: 06/18/2021 | Published: 06/25/2021

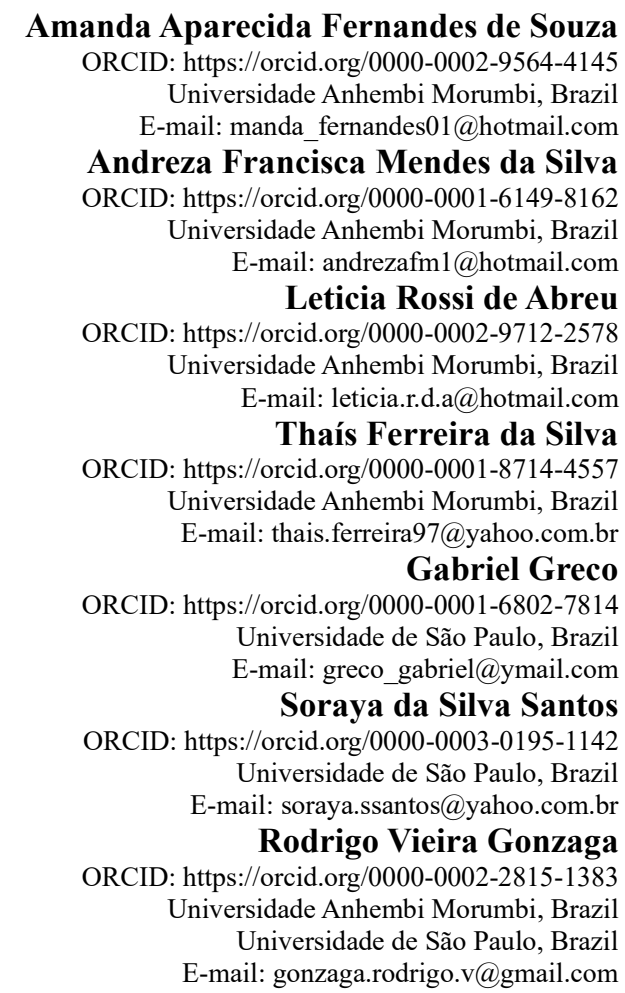

\begin{abstract}
The therapeutic properties of Cannabis have been described since antiquity and are of great relevance for the Egyptian, Chinese, Indian, Arab and Latin people. Cannabis-based medicines show several therapeutic purposes, mainly to treat disorders as constipation, some types of pain, epilepsy, anxiety and among others. In addition, the genus Cannabis exhibits great clinical relevance due to its Central Nervous System activities attributed to some phytochemicals compounds, as cannabidiol and $\Delta 9$-tetrahydrocannabinol. The interest in the pharmacological properties of Cannabis is growing and several new studies are being carried out to prove its pharmacotherapeutic use which are important to design of novel drugs with different routes of administration and for multiple pathologies resistant to the conventional treatments. In this context, there is a pressure on countries to review the laws that still limit the research development related to medicinal Cannabis purposes. Herein, our aim is to perform an overview about the plant, endocannabinoid system, Cannabis-based medicines and clinical uses, regulatory aspects of Cannabis sp and its chemical compounds of therapeutic interest.
\end{abstract}

Keywords: Cannabis sp.; Medicinal cannabis; Medical cannabis; Cannabinoids; Cannabis sativa; Marihuana.

\section{Resumo}

As propriedades terapêuticas da Cannabis são descritas desde a antiguidade e são de grande relevância para os povos egípcios, chineses, indianos, árabes e latinos. Os medicamentos à base de Cannabis apresentam vários fins terapêuticos, principalmente para tratar distúrbios como a constipação, alguns tipos de dor, epilepsia, ansiedade, entre outros. Além disso, o gênero Cannabis apresenta grande relevância clínica devido seu efeito sobre o Sistema Nervoso Central atribuído a alguns compostos fitoquímicos, como o canabidiol e o $\Delta$ 9-tetrahidrocanabinol. O interesse pelas propriedades farmacológicas da Cannabis é crescente e vários novos estudos estão sendo realizados para comprovar seu uso farmacoterapêutico, estudos que são importantes para o planejamento de novos fármacos com diferentes vias de administração e para múltiplas patologias resistentes aos tratamentos convencionais. Nesse contexto, há uma pressão sobre os países para que revisem as legislações que ainda limitam o desenvolvimento de pesquisas relacionadas aos fins medicinais da Cannabis. Aqui, nosso objetivo é realizar uma visão geral sobre a planta, sistema endocanabinoide, 
medicamentos à base de Cannabis e usos clínicos, aspectos regulatórios da Cannabis sp e seus compostos químicos de interesse terapêutico.

Palavras-chave: Cannabis sp.; Cannabis medicinal; Canabinóides; Cannabis sativa; Maconha.

\section{Resumen}

Las propiedades terapéuticas del Cannabis se han descrito desde la antigüedad y son de gran relevancia para los pueblos egipcio, chino, indio, árabe y latino. Los medicamentos a base de Cannabis tienen varias finalidades terapéuticas, principalmente para tratar trastornos como el estreñimiento, algunos tipos de dolor, la epilepsia, la ansiedad, entre otros. Además, el género Cannabis tiene una gran relevancia clínica debido a su efecto sobre el Sistema Nervioso Central atribuido a algunos compuestos fitoquímicos, como el cannabidiol y el $\Delta 9$-tetrahidrocannabinol. Crece el interés por las propiedades farmacológicas del Cannabis y se están realizando varios nuevos estudios para comprobar su uso farmacoterapéutico, estudios que son importantes para la planificación de nuevos fármacos con diferentes vías de administración y para múltiples patologías resistentes a los tratamientos convencionales. En este contexto, se ejerce presión sobre los países para que revisen la legislación que aún limita el desarrollo de la investigación relacionada con los fines medicinales del Cannabis. Aquí, nuestro objetivo es proporcionar una descripción general de la planta, el sistema endocannabinoide, los medicamentos a base de Cannabis y los usos clínicos, los aspectos regulatorios de Cannabis sp y sus compuestos químicos de interés terapéutico.

Palabras clave: Cannabis sp.; Cannabis medicinal; Cannabinoides; Cannabis sativa; Marijuana.

\section{Introduction}

The Therapeutic effects of Cannabis sp have been reported since ancient times for several medicinal purposes, such as constipation, some types of pain, epilepsy, anxiety, among others (Fankhauser, 2002; Pamplona, 2014; Pain, 2015; Pisanti, Bifulco, 2017). In 1830, the German Theodor Friedrich Ludwig Nees von Esenbeck was the first to describe the therapeutic uses of Cannabis indica. In 1839, William Brooke O'Shaughnessy related his clinical experiences with Cannabis in India, highlighting its therapeutic potential to modern medicine (Grotenhermen, Müller-Vahl, 2016). Initially, he performed experimental studies in animals to verify safety, then O'Shaughnessy tested the Cannabis in patients with tetanus, epilepsy, cholera or rheumatism. The findings showed Cannabis analgesic, and myorelaxant activities. Regarding tetanus and epilepsy, Cannabis was not able to cure, though it is known as an adjuvant, increasing the treatment efficiency (Cunha et al., 1980; Leghissa et al., 2017; Pisanti, Bifulco, 2017). The Italian Raffaele Valier (1887) observed that inhalation of $C$. sativa or $C$. indica presented similar effects and were effective for the treatment of neuralgia, insomnia, migraine, pulmonary emphysema and asthma (Pisanti, Bifulco, 2019).

Several researches have shown the potential medicinal activity of Cannabis and its chemical compounds. There is still a huge prejudice in society in relation to medical Cannabis due to its recreational use. However, this scenario is changing, and the social resistance is decreasing for the medicinal use of Cannabis. In this context, plant derivatives were identified, such as $\Delta 9$-tetrahydrocannabinol ( $\triangle 9$-THC or THC) and cannabidiol (CBD), as well as, the endocannabinoid system, cannabinoid receptors type 1 and type 2 (CB1 and CB2, respectively) (Mechoulam, Parker, 2013; Macarrone et al., 2015; Pain, 2015; Grotenhermen, Müller-Vahl, 2016; Pisanti, Bifulco, 2017). Herein, our aim is to provide an overview about the plant, endocannabinoid system, available Cannabis-based medicines and clinical uses, regulatory aspects of Cannabis sp and its chemical compounds of therapeutic interest.

\section{Methodology}

This research is an integrative literature review of a qualitative nature regarding medicinal uses of Cannabis. The study was based on the analysis of scientific papers that cover: the plant characteristics, its therapeutic properties, endocannabinoid system and regulatory aspects of Cannabis sp. The databases employed were: Scielo, Google Academic, Pubmed and Researcher (application, version 2.10.3). Some parameters were established for researching, such as: theme identification; definition of inclusion and exclusion criteria, as articles indexed in journals classified by QualisCAPES in A and B; identification, preselection and categorization of papers; analysis and interpretation of results and presentation of the review/synthesis of 
knowledge.

In order to research, the following key words were employed: "cannabinoids", "medicinal Cannabis", "THC pharmacodynamic", "medicines cannabinoids", "medicinal use Cannabis sativa", "endocannabinoids", "endocannabinoid system", "pharmacokinetics cannabinoids". A total of 104 articles were selected, being that 15 papers related to Cannabis composition, 13 about endocannabinoids and 49 regarding the therapeutic use of $C$. sativa and other information. Considering the exclusion criteria, 77 articles were chosen to build the study, besides current legislation on the medicinal use of Cannabis. In the Figure 1 shows the flowchart employed to the study development. Additionally, the information related to the medicines and extracts on the commercially available, mainly reports from pharmaceutical industries responsible for production, in addition to legal documents from regulatory agencies of some countries were employed.

Figure 1. Flowchart of the article selection process and inclusion criteria of studies.

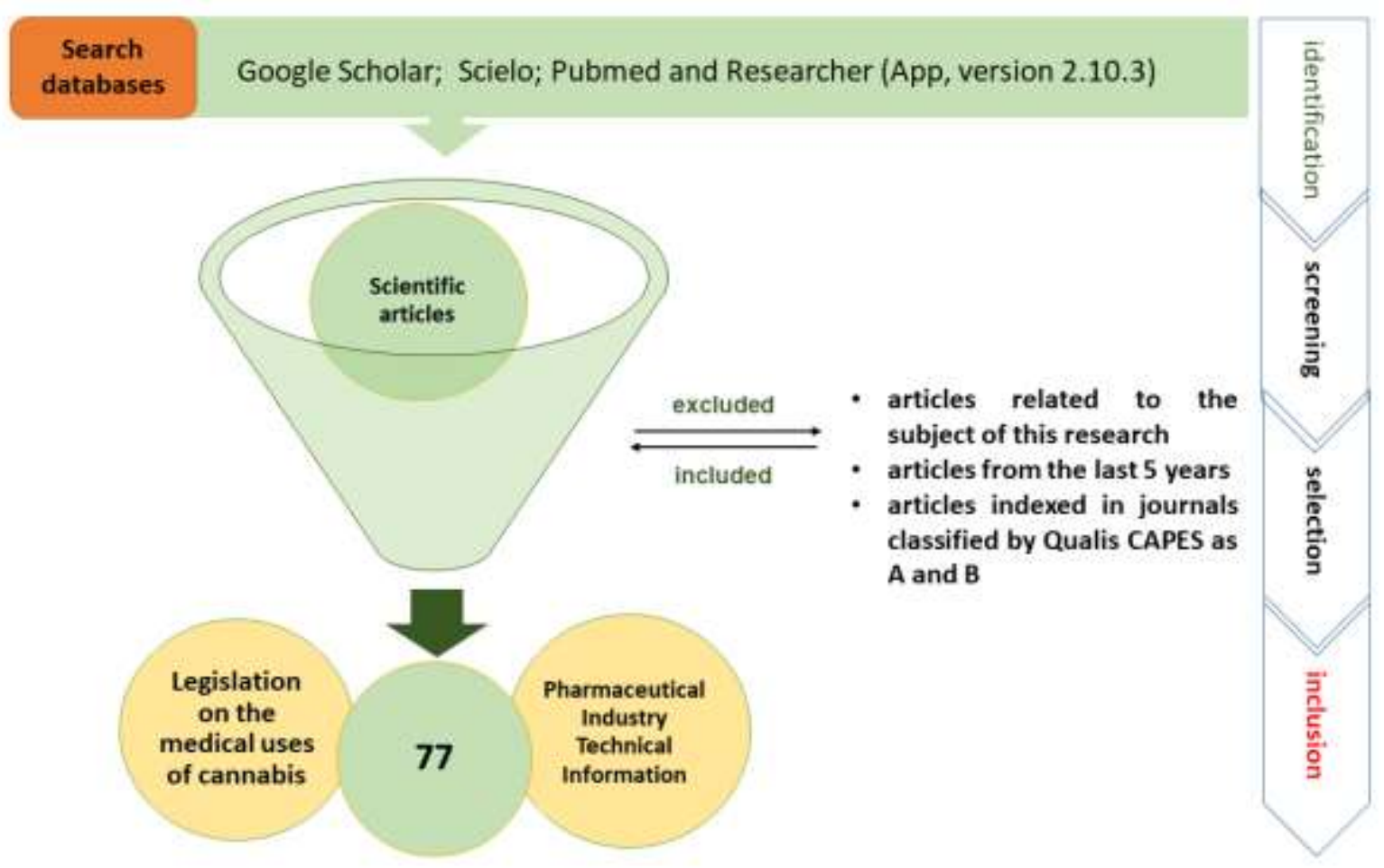

Source: Authors.

\section{Plant Characteristics}

First Cannabis sativa records were in Central Asia around 4000 years b.C., more precisely in China (Russo et al., 2008; Fathordoobady et al., 2019). Cannabis is a genus of angiosperm from Cannabaceae family (Zlas et al., 1993; Tagne et al., 2019) (Figure 2), being botanically classified as an annual herbaceous plant and its leaves are thin, pointed and serrated. There are three Cannabis strains: sativa, indica and, ruderalis (Figure 3). The Figures 2 and 3 demonstrate the Cannabis species employed therapeutically. Cannabis can be female plant, being more robust, or male one, whose main role is to pollinate the female flowers and, it is rarely hermaphrodite (Lewis et al., 2017). 
Figure 2. Cannabis sativa.

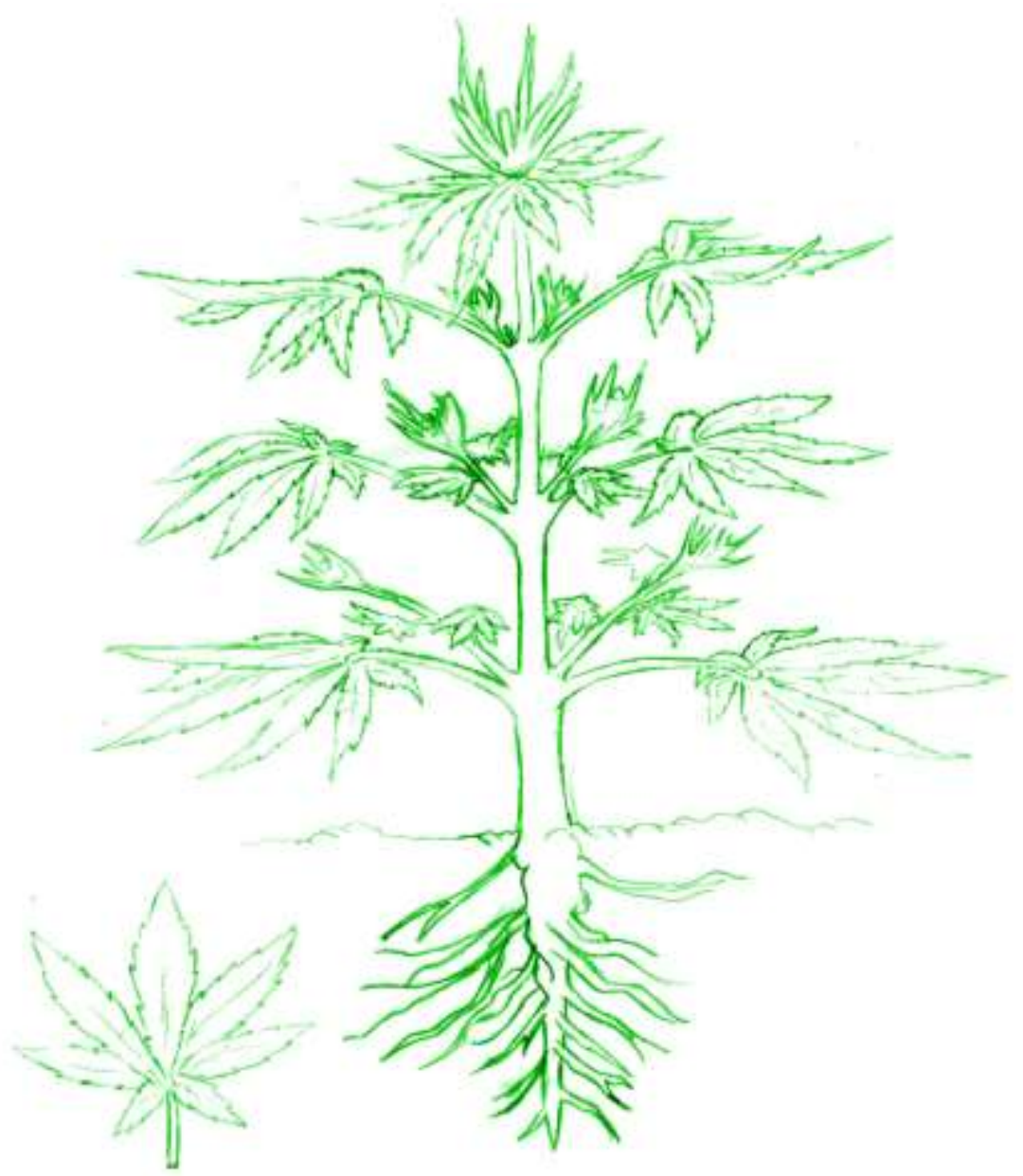

Source: Authors.

Figure 3. Botanical difference between species of the Cannabaceae family.

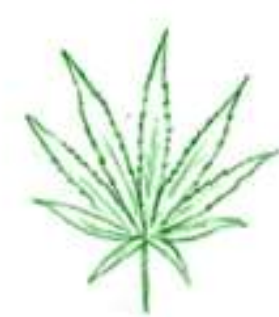

sotivo

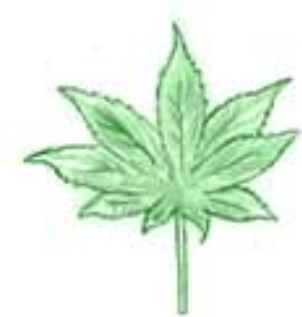

Indice

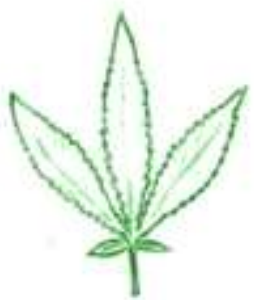

ruderedis

Source: Authors.

Cannabis contains a wide range of compounds, including fatty acids (protect cell membranes), cannabinoids (active in CB1 or CB2 receptors), flavonoids (plant pigments and control of cell growth), phenols (as THC), terpenes (confer smell), and other secondary metabolites are still under investigation (Lewis et al., 2017). Furthermore, in Cannabis are found substances beneficial to health with nutritional value, such as: vegetable oils between 19-38\%, protein around 20-30\%, fiber ranging from 27-36\%, minerals between 4-6\%, besides tocopherol, carotenes and other phenolic compounds (Fathordoobady et al., 2019). There are around 550 chemical constituents identified in the Cannabis sativa, being 113 phytocannabinoids and 120 terpenes (Aizpurua-Olaizola et al., 2016), though only 90 components were purified and characterized (Fathordoobady et al., 2019). 
Cannabinoids are isolated from leaves, flowers, stems, roots and seeds, but the main source of phytocannabinoids are trichomes of unfertilized female flowers, which secrete a resin loaded of phytocannabinoids, as the THC (López et al., 2014; Pollastro et al., 2017; André, Hausman, Guerreiro, 2016).

According to André and colleagues (2016), there are limitations regarding the research of phytochemical constituents and clinical aspects of Cannabis, due to illegal cultivation or manufacturing in many countries, such as Brazil, and also different cultivation conditions. The most important and abundant pharmacological compounds are the cannabinoids: cannabinol (CBN), CBD and THC, the Figure 4 presents the chemical structures of therapeutic agents. CBN is a THC metabolite, with potential immunosuppressive and anti-inflammatory activities. THC exhibits a great homeostatic influence at the Central Nervous System (CNS) (Glass et al., 1997; Russo, 2016). CBD is considered a non-psychoactive agent and CB1 and CB2 receptors antagonist, even in small concentrations (Russo, 2011; André, Hausman, Guerreiro, 2016).

Figure 4. Chemical structure of CBN (1), THC (2) and CBD (3).

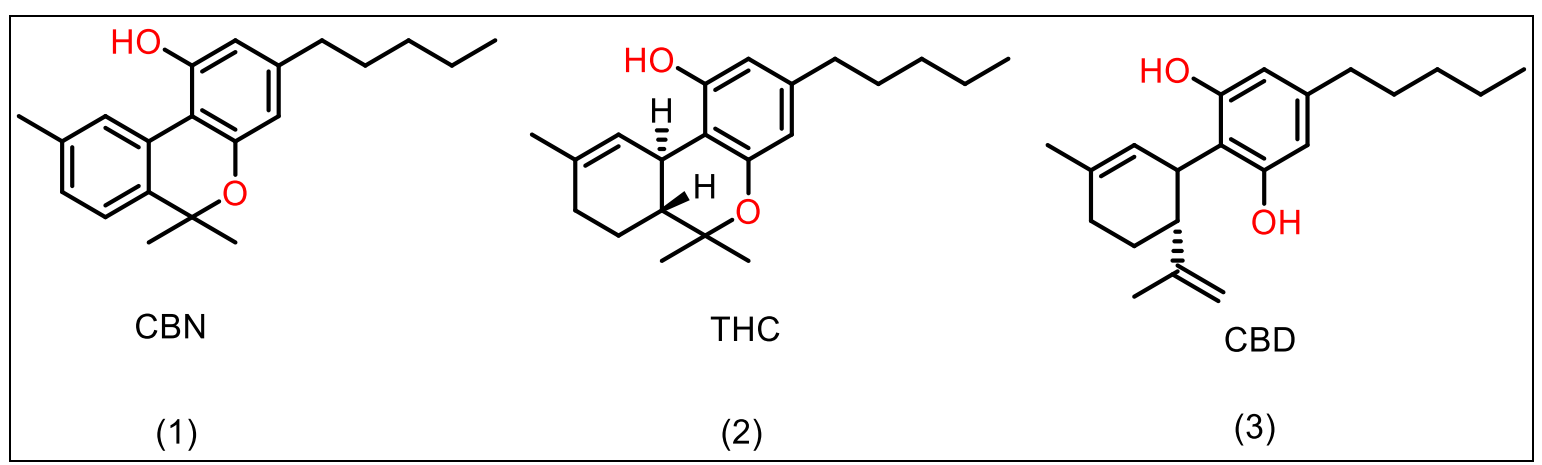

Source: Authors.

Researches have been revealed the cannabinoids potentialities on the treatment of neuropathic, pelvic, pancreatic pains, fibromyalgia, overactive bladder, dermatological diseases, migraine, irritable bowel syndrome, among others (Russo, 2016). The finding of new Cannabis constituents has been exponential and constant due to the growing interest in the therapeutic potential shown by strains (Russo, 2004; WHO, 2015).

\section{Endocannabinoid System}

The endocannabinoid system (ECS) is composed of cannabinoid receptors, endocannabinoids (EC), enzymes and proteins related to their synthesis, transport and degradation. In the 1960s, the discovery of $\Delta 9$-THC was the first step in developing the ECS hypothesis, then there was the elucidation of CB1 receptor in the brain, where $\triangle 9$-THC binds, as well as, CB2 receptor in immune cells (Munro, Thomas, Abu-Shaar, 1993; Stella, 2009; Di Marzo, Stella, Zimmer, 2015; Lutz et al., 2015; Nicolussi, Gertsch, 2015; Parsons, Hurd, 2015; Iannotti, Di Marzo, Petrosino, 2016; Morena et al., 2016).

Cannabinoid receptors are metabotropic G protein-coupled receptors (Devane et al., 1988; Di Marzo, Stella, Zimmer, 2015; Atwood, Mackie, 2010; Wei et al., 2017). CB1 receptor is encoded by the CNR1 gene, consisting of 472 amino acids in humans and there are two isoforms containing a shorter N-terminus (Devane et al., 1988; Shire et al., 1995; Ryberg et al., 2005; Pertwee, 2010; Di Marzo, Stella, Zimmer, 2015; Grotenhermen, Müller-Vahl, 2016; Iannotti, Di Marzo, Petrosino, 2016; Zou, Kumar, 2018). CB1 receptors are mainly located at axon terminals and their activation causes high suppression of neurotransmitters by regulating neuronal activity and chemical mediator releasing. CB1 mechanism consists of inhibiting adenylyl cyclase, resulting in decreasing cyclic adenosine monophosphate (cAMP) or activation of mitogen-activated protein kinases (MAPK) and it is also associated with inhibition of N-type calcium channels (Howlett, 1998; Turu, Hunyady, 2010; 
Iannotti, Di Marzo, Petrosino, 2016; Morena et al., 2016; Zou, Kumar, 2018). CB2 receptors are more concentrated in immune system cells, though CB2 has also been found in neuronal, glial and brain endothelial cells. CB2 receptors may regulate the neuronal excitability through modulation of the calcium-activated chloride channels, but information regarding their role in neuronal regulation are still scarce (Den et al. 2012; Parsons, Hurd, 2015; Iannotti, Di Marzo, Petrosino, 2016; Zou, Kumar, 2018).

The endogenous ligands for these receptors are $\mathrm{N}$-arachidonoyl ethanolamine, named anandamide (AEA), and 2arachidonoyl glycerol (2-AG), both compounds are the main known endocannabinoids (Figure 5) (Di Marzo, Stella, Zimmer, 2015; Nicolussi, Gertsch, 2015; Iannotti, Di Marzo, Petrosino, 2016; Zou, Kumar, 2018). AEA has higher affinity for CB1 than CB2 receptor, being a weak agonist. In addition, AEA activates the vanilloid receptor 1 (TrpV1), which possibly participates in endocannabinoid signaling, through inhibition of L-type calcium channels, as well as in the downregulating of 2-AG biosynthesis (Gonsiorek, 2000; Morena et al., 2016; Zou, Kumar, 2018). 2-AG is a moderate to weak cannabinoid receptor agonist and is related to the sustained neuronal depolarization and, mediation of multiple forms of synaptic plasticity (Di Marzo, Petrocellis, 2012; Morena et al., 2016; Zou, Kumar, 2018). In the Figure 5 are displayed other endocannabinoids as: virodhamine, which is a moiety of arachidonoyl coupled to an ethanolamine by an ester bond, acts as a full and selective CB1 agonist; $N$-arachidonyldopamine (NADA) is a CB1 agonist and potent activator of $\operatorname{TrpV1}$; and palmitoylethanolamide (PEA) is involved with antiinflammatory, analgesic and neuroprotective processes (Petrosino, Di Marzo, 2010; Nicolussi, Gertsch, 2015; Iannotti, Di Marzo, Petrosino, 2016). ECs acts in the reduction of synaptic transmission by several mechanisms with important action on CB1, but there are still few evidences of CB2 activity on CNS modulation (Lutz et al., 2015; Zou, Kumar, 2018).

Figure 5. Endocannabinoid structures: (4) anandamide; (5) 2-AG; (6) virodhamine; (7) NADA; (8) PEA.

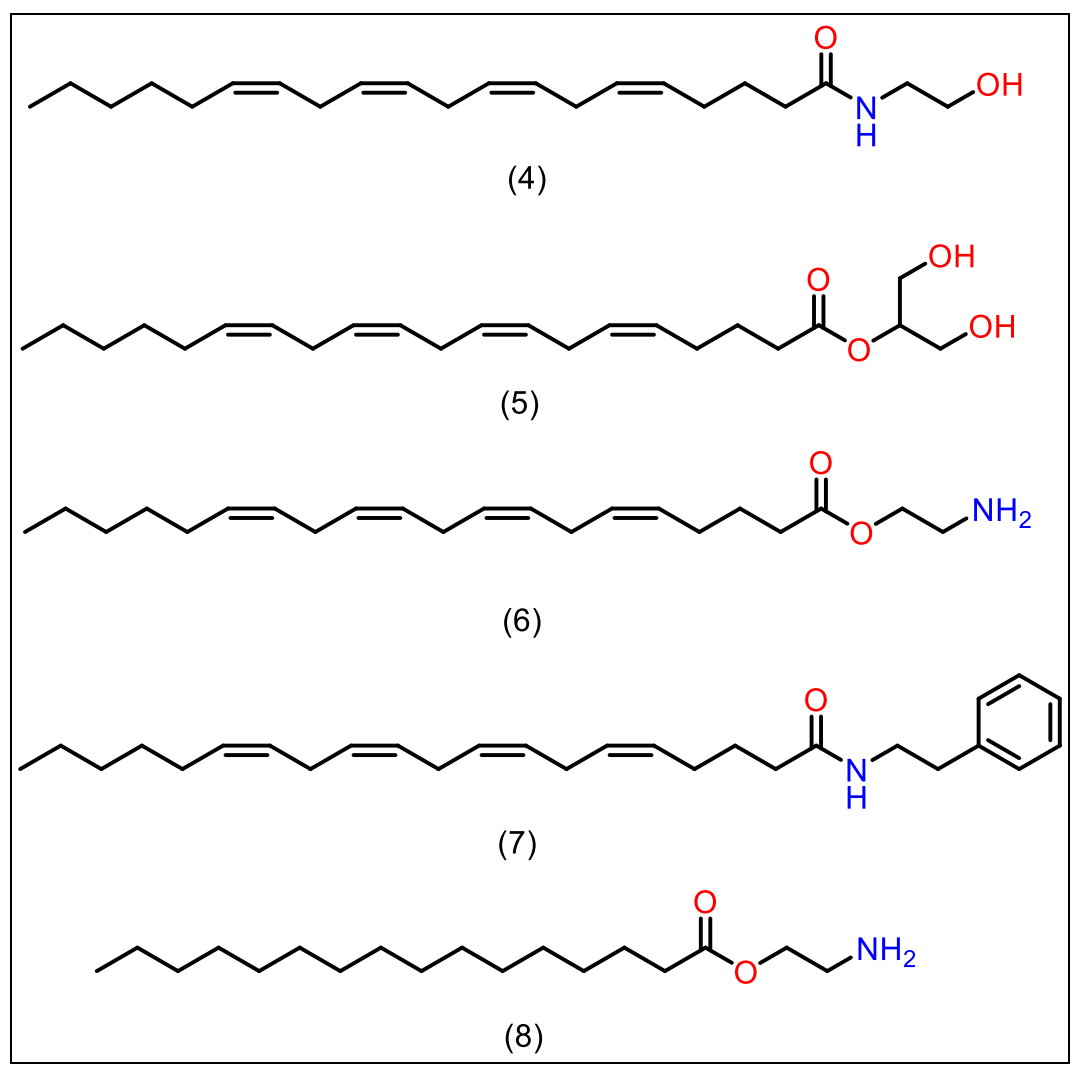

Source: Authors. 


\section{Cannabis-based Medicines}

Raphael Mechoulam developed a hypothesis to explain the therapeutic action of Cannabis sp., named "entourage effect", which is characterized by synergistic activity of phytocannabinoids with other plant secondary metabolites. This theory was based on the observation that the presence of phytocannabinoids, glycerol fatty acid esters, alongside 2-AG, reduced the hydrolysis rate of 2-AG, increasing its activity. Currently, the entourage effect has been contested by searches that have proven the same therapeutic action of isolated compounds and phytocomplexes (Hazekamp et al., 2013; Bonn-Miller, Loflin, Chandra, 2018).

Cannabis-based medicines are marketed in many countries, either as herbaceous products, Cannabis extract or isolated cannabinoid drugs. In Netherlands, herbaceous products and dried unfertilized female flowers, named "flos" are sold e may be administered orally or by inhalation. Other preparations are liquid extracts from Cannabis, which can be administered by sublingual route or even in food and capsules containing standardized THC and CBD concentrations. Standardized Cannabis extracts are prepared by drying processes, thus the final product remains of high levels of bioactive agents from vegetable drug (Hazekamp et al., 2013; Parmar, Forrest, Freeman, 2016; Grof, 2018).

In the Figure 6 is demonstrated the decarboxylation reaction after heating from tetrahydrocannabinolic acid-A (THCAA) and cannabidiolic acid (CBDA), compounds with the highest concentration in the plant, and after this process results in bioactive compounds THC (2) and CBD (3), respectively. By inhalation, the maximum plasma concentration is reached within 3 to 10 minutes, after 15 minutes the concentration decreases to about $60 \%$ and, in 20 minutes is already around $20 \%$. Thereby, the bioavailability is variable and depends on factors as number of inhalations and breath-holding duration (Grant, 2012; Borodovsky et al., 2016; Lanz et al., 2016; Lucas, Galettis, Schneider, 2018; Maccallum, Caroline, Russo, 2018; Martin et al., 2018).

There are Cannabis vaporizers able to aerosolize and disperse cannabinoids, in which the dried drug or extract are electronically heated at a lower temperature than burn. This process provides the decarboxylation of compound in a mixture of water vapor. Taking this into account, the vaporizers received attention for therapeutic use, as they present lower respiratory hazards than other Cannabis combustion products. The vaporizers have pharmacodynamics and pharmacokinetics like compounds derived from thermal decomposition of burning. Furthermore, there is a difference between the vaporizer types, being that the electric ones with controlled temperature perform the decarboxylation better than gas-powered vaporizers (Biehl, Burnham, 2015; Newmeyer et al., 2017; Russell et al., 2018). 
Figure 6. Decarboxylation reaction after heating of THCA-A (9) and CBDA (10), resulting in bioactive compounds THC (2) and CBD (3), respectively.

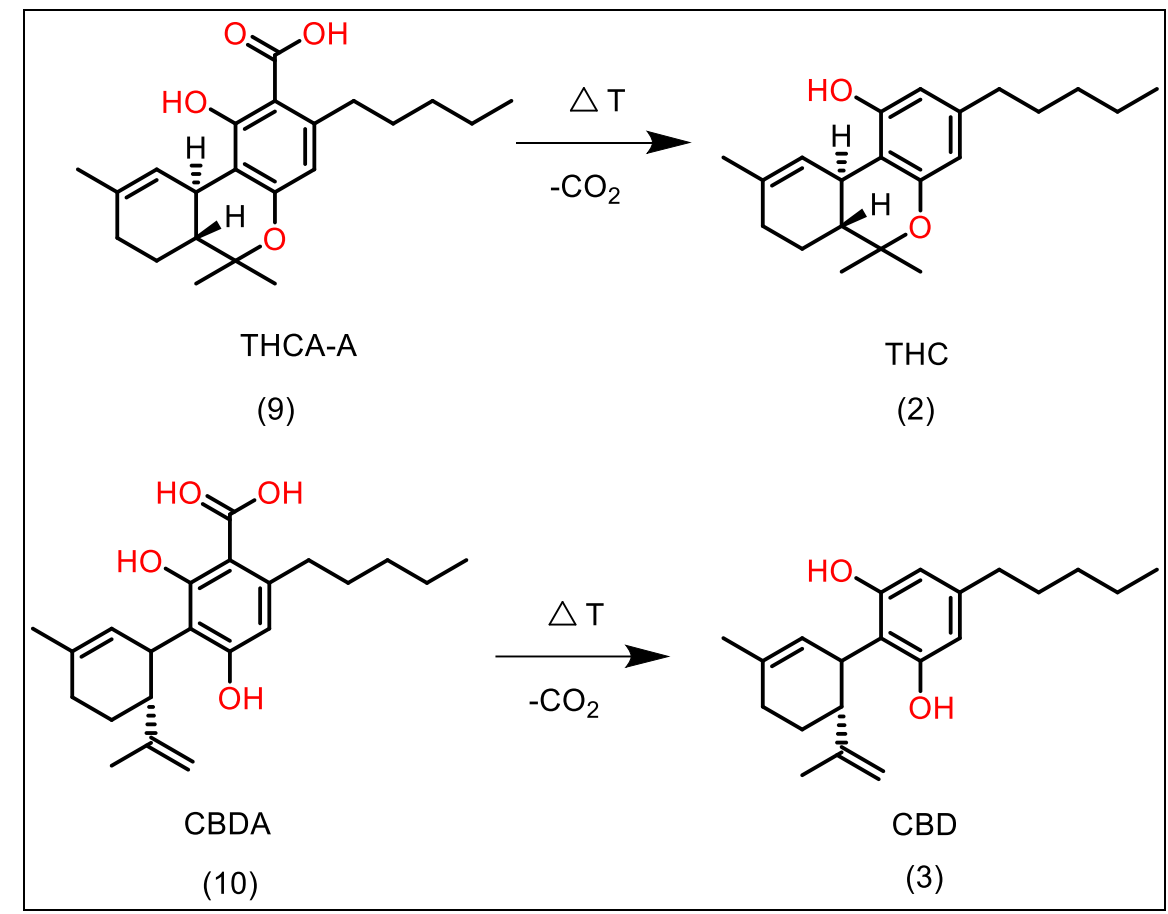

Source: Authors.

\section{Cannabinoids Pharmacokinetics and Side Effects}

Cannabinoids are highly lipophilic, they often need a carrier to facilitate their absorption into oral and topical routes. Oral absorption of THC and CBD range from 10 to 20\%, being slow, erratic, unpredictable by THC, which is sensitive to gastric acid. Additionally, the type of feeding and the first pass effect on the intestine and liver can interfere in bioavailability. Maximum concentration happens within 1 to 6 hours upon ingestion and has prolonged action. Formulations designed to buccal mucosa present faster and higher absorption than oral route, useful for rapid symptom relief (Huestis, 2007; Maccallum, Caroline, Russo, 2018). The transdermal route does not suffer the first pass effect and ensures more limited local action. However, there is a great difficulty for transdermal release, which requires the improvement and development of new technologies for drug delivery (Grant, 2012; Lanz et al., 2016; Carcieri et al., 2018; Lucas, Galettis, Schneider, 2018; Maccallum, Caroline, Russo, 2018).

The distribution of cannabinoids is fast on highly vascularized tissues, as lung and brain, whereas in least vascularized regions, they are distributed by balance. In chronic use, these compounds can accumulate in adipose tissue, cannabinoids are released and redistributed, providing prolonged action. THC predominantly undergoes hepatic metabolism by cytochrome P450, especially by CYP2C9, CYP2C19 and CYP3A4 isoenzymes, though organs as small intestine and brain also metabolize it. The main metabolites of THC are 11-hydroxy-THC and 11-carboxy-THC, which suffer glucuronidation and are excreted via feces and urine. The half-life of THC ranges from the initial half-life (approximately 6 minutes) and the longer half-life (22 hours) (Hunt, Jones, 1980; Lucas, Galettis, Schneider, 2018).

CBD is metabolized in the liver by isoenzymes CYP2C19, CYP3A4, CYP1A1, CYP1A2, CYP2C9 and CYP2D6, it undergoes hydroxylation resulting in 7-hydroxy cannabidiol, followed by other metabolism steps and, finally its metabolite is eliminated in the feces and a lesser extent by urine. The mean half-life of CBD ranges from 18 to 30 hours when administered intravenously, from 27 to 35 hours by inhalation route, and 2 to 5 days by oral use (Lemberg, Crabtree, Rowe, 1972; Eichler et al., 2012; Schwope et al., 2011; Lucas, Galettis, Schneider, 2018). 
Acute and chronic side effects related to Cannabis sp. are gastrointestinal disorders, fatigue, hypotension, nausea, paranoia, psychiatric symptoms, dizziness, impaired neurocognitive and psychomotor performances, attention and memory deficits, increase of psychiatric disorders, risk for addiction, airway trauma and lung diseases. Regarding the synthetic cannabinoids, acute adverse events are tachycardia, acute myocardial infarction, acute kidney injury, seizure, sedation, confusion and impaired motor skills, while the prolonged use is associated with withdrawal symptoms, including restlessness, anxiety and mood swings (Cranford et al., 2016; Parmar, Forrest, Freeman, 2016; Akram, Mokrysz, Curran, 2019). Considering the several adverse effects, the treatment with Cannabis sp. is contraindicated in patients with psychiatric, cardiovascular, renal or liver diseases. In addition, cannabinoids cross the placenta even at lower doses and are carried to breast milk, thus they are not recommended for pregnant and lactating women, as they can cause newborn weight-loss and neurobehavioral disorders (TGA, 2013; Parmar, Forrest, Freeman, 2016; Lucas, Galettis, Schneider, 2018).

Available Cannabinoid-based medicines

The Table 1 highlights and summarizes the commercially available cannabinoid drugs, which are employed to different therapeutic applications.

Table 1. Approved drugs containing synthetic cannabinoids and/or natural extracts of Cannabis sativa or indica.

\begin{tabular}{|c|c|c|}
\hline Product & $\begin{array}{c}\text { Active } \\
\text { principles }\end{array}$ & Therapeutic indications \\
\hline Acomplia $^{\circledast}$ & Rimonabant & $\begin{array}{l}\text { Appetite suppressant for obesity/overweight treatment } \\
\text { (Smerp, 2019) }\end{array}$ \\
\hline Marinol $^{\circledR}$ & Dronabinol & Treatment of nausea and vomiting in cancer or AIDS patients (Becker, Nardin, 2011) \\
\hline Cesamet $^{\circledR}$ & Nabilone & Treatment of nausea and vomiting in cancer or AIDS patients (Becker, Nardin, 2011) \\
\hline Bedrocan $^{\circledast}$ & THC e CBD & $\begin{array}{l}\text { Treatment of insomnia, neuropathic pain, stress, spasms, multiple sclerosis and depression (Bedrocan, } \\
\text { 2019) }\end{array}$ \\
\hline Sativex $^{\circledR}$ & THC e CBD & $\begin{array}{l}\text { Treatment of spasticity related to multiple sclerosis } \\
\qquad \text { (Gw Pharmaceuticals, 2019a) }\end{array}$ \\
\hline Epidiolex ${ }^{\circledast}$ & $\begin{array}{l}\text { CBD } \\
(98 \%)\end{array}$ & $\begin{array}{l}\text { Treatment of seizures associated with Lennox-Gastaut and/or Dravet syndrome (Gw Pharmaceuticals, } \\
\qquad 2019 \mathrm{~b})\end{array}$ \\
\hline Mevaty $\left.\right|^{\circledR}$ & THC e CBD & $\begin{array}{l}\text { Treatment of spasticity related to multiple sclerosis } \\
\qquad \text { (Gw Pharmaceuticals, 2019c) }\end{array}$ \\
\hline
\end{tabular}

Source: Authors.

In 1983, Cesamet ${ }^{\circledR}$ and Marinol ${ }^{\circledR}$ were approved by FDA, in order to treat nausea and vomiting in cancer and AIDS patients, when conventional therapies present no more effects (Barnes, 2006; Becker, Nardin, 2011). Cesamet®, whose active 
principle is nabilone (Figure 7), a synthetic THC analogue, was initially marketed by Eli Lilly, which discontinued production in 1989 on commercial reasons. In 2004, Valeant Pharmaceuticals acquired the nabilone rights, but the approval for commercialization happened in 2006. Currently, Cesamet ${ }^{\circledR}$ is sold in the United States and Europe (Fonseca et al., 2013). Nabilone has several adverse effects, the most observed are drowsiness, dizziness, dry mouth, euphoria, ataxia, headache and concentration problems. Although the nabilone structure is different from THC, it presents the same pharmacological activity, interacting similarly to the THC, as partial agonist on CB1 receptors and a small part on CB2. It is important to highlight that nabilone is more psychoactive than THC, thus it causes more side effects than the latter (FDA, 2019a; Pamplona, 2014).

Marinol ${ }^{\circledR}$ contains the active principle dronabinol, the synthetic THC, and is marketed by AbbVie Pharmaceuticals in Canada and the United Kingdom. Dronabinol is a sympathomimetic drug and its most common adverse events are anorexia, asthenia, heart palpitations, ataxia, confusion, euphoria and drowsiness. Therefore, its use is limited due to several side effects (Clermont-Gnamien et al., 2002; Cichewicz, McCarthy, 2003; FDA, 2006; Lessa et al., 2016).

In 2003, Bedrocan, a Dutch pharmaceutical company, received authorization from Netherlands Ministry of Health to produce and distribute standardized extracts of $C$. sativa and $C$. indica for medicinal uses. Currently, Bedrocan owns several extracts with specific concentrations of THC and CBD. Products from Bedrocan on the market are: Bedrocan ${ }^{\circledR}$ containing THC at $22 \%$ and $\mathrm{CBD}$ at $1 \%$ (2003), Bedrobinol ${ }^{\circledR}$ containing THC at $13.5 \%$ and $\mathrm{CBD}$ at $1 \%$ (2005), Bediol@ with THC at $6.3 \%$ and CBD at $8 \%$ (2007), Bedica ${ }^{\circledR}$ with THC at $14 \%$ and CBD at $1 \%$ (2011), and Bedrolite ${ }^{\circledR}$ containing THC at $1 \%$ and CBD at $9 \%$ (2014). These products are indicated for insomnia, neuropathic pain, stress, spasms, multiple sclerosis, and depression. Therefore, it is essential to evaluate the risk-benefit, according to the clinical needs of patients (Bedrocan, 2019; Pamplona, 2014).

Rimobabant (Figure 7 - Acomplia ${ }^{\circledR}$ from Sanofi-Aventis) was a selective CB1 receptor antagonist, it inhibits 2arachidonoylglycerol activity, causing the decrease hunger, since this endocannabinoid modulates the appetite. Therefore, rimonabant was employed to treat obese and overweight patients with health risks. In 2007, the drug was approved in Brazil as film-coated tablets containing $20 \mathrm{mg}$ rimonabant, being a controlled drug (Valvassori et al., 2011; Ribeiro, 2014; Crippa et al., 2010; Smerp, 2019). However, in 2008, the product was suspended worldwide, due to the high risk of developing mental illness, such as anxiety, depression and suicidal thoughts (Fonseca et al., 2013). The Figure 7 shows rimonabant and nabilone structures, both drugs were designed from natural cannabinoids, being that rimonabant is an antagonist and nabilone is a partial agonist of endocannabinoid system.

Figure 7. Cannabinoid-based drugs (11) rimonabant and (12) nabilone.

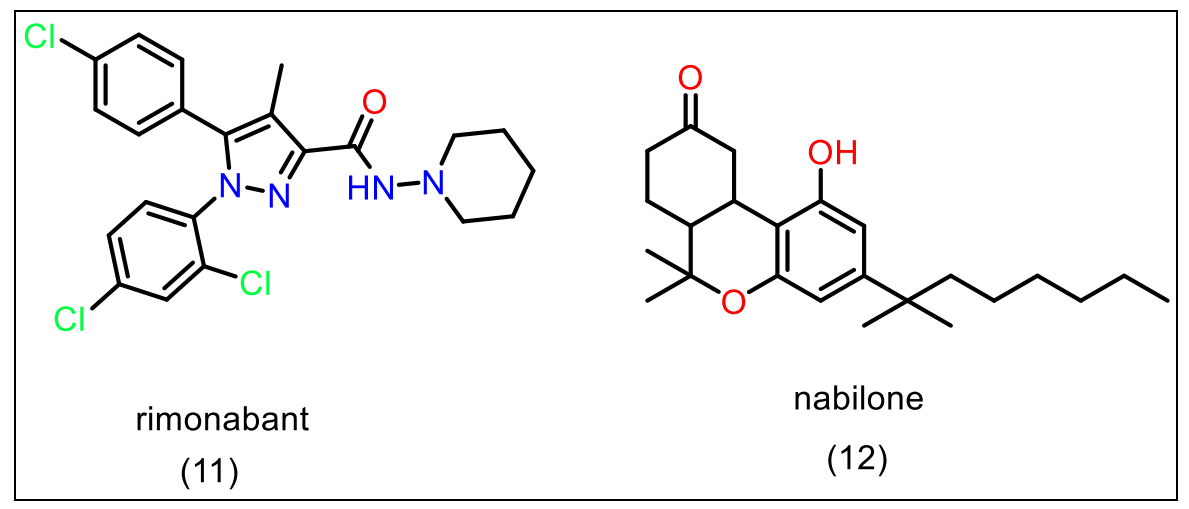

Source: Authors.

The first legal Cannabis-based drug approved in some countries was Sativex®, produced by GW Pharmaceuticals, it 
consists of an oral spray composed of two cannabinoids: THC and CBD in 1:1 ratio. THC acts as a CB1 and CB2 receptors partial agonist, performing an important role in retrograde signaling in the regulation of synaptic. CBD and THC inhibit the endocannabinoid system, researches have been shown that cannabinoid receptor antagonists modulate muscle stiffness. Therefore, this medicine is indicated to treat moderate to severe spasticity related to multiple sclerosis in patients unresponsive to conventional therapy (Ribeiro, 2014; Drugbank.Sativex, 2019; Lessa et al. 2016). Regarding the side effects are described dizziness, anorexia, depression, disorientation, constipation, among others (ANVISA, 2017). Sativex ${ }^{\circledR}$ began to be marketed in Canada in 2005. Currently, it was approved and sold in the United Kingdom, Germany, Denmark, Sweden, Switzerland, Canada, Australia, New Zealand, Israel, the United States and, Brazil. In addition, FDA approved it as pain relief medicines (Russo, Guy, 2006; GW Pharmaceuticals, 2019a; Fonseca et al., 2013; Lessa et al., 2016). In Brazil, Sativex ${ }^{\circledR}$ is marketed using the Mevatyl ${ }^{\circledR}$ brand, as an antispasmodic drug distributed by Ipsen Pharmaceuticals, being approved in January 2017 and sold as a controlled substance (Smerp, 2019).

In 2018, FDA approved Epidiolex ${ }^{\circledR}$ (GW Pharmaceuticals), a CBD extract at 98\%, which consists of an oral solution indicated for treating seizures associated with Lennox-Gastaut or Dravet syndromes. Epidiolex $®$ acts as an endocannabinoid, inhibiting to CB1 and CB2 receptors. In relation to the adverse events, Epidiolex may cause hepatocellular injury, drowsiness, sedation, suicidal thoughts, and hypersensitivity reactions (Matos et al., 2017; Gw Pharmaceuticals, 2019b; Drugbank.Epidiolex, 2019; FDA, 2019b).

\section{Legislation on Cannabis-based Products}

Herein, we focused on Brazilian regulation, though other countries have been mentioned. In Brazil, based on the increase in judicial petitions requesting the importation of medicinal Cannabis products, the Brazilian Health Regulatory Agency (ANVISA) published the first regulation on the subject through Resolution RDC $\mathrm{n}^{\circ} 17 / 2015$, which defines the criteria and procedures for importing of products containing cannabidiol and other cannabinoids for the health treatment. In order to import, it is required the prescription of a legally qualified professional for patient own use, thus by restricting to patients with the need attested to the product (Brazil, 2015). An ANVISA update in 2016 of the Ordinance $n^{\circ} 344$ of 1998 included CBD and THC on the list of substances of special control, through the Resolution RDC n ${ }^{\circ} 66$ (March 2016), regulating the use of medicinal Cannabis-derived products, since the Cannabis sativa is still on the list of plants prohibited in Brazil, due to its recreational use (Brazil, 2016). In addition, Cannabis sativa was included as a medicinal plant in Common Brazilian Denomination by Resolution RDC n 156 (May 2017) (Brazil, 2017). Recently, the Resolution RDC n 327 of December 9, 2019 established the required quality parameters for the regulation of these products from the granting of health authorization for the manufacture and import to the criteria for use in the marketing, prescription, dispensing, monitoring and inspection of Cannabis-based drugs for medicinal purposes (Brazil, 2019).

In other Latin America countries such as Peru, Argentina and Mexico, there was needed the pressure from citizens and patients for the approval of policies that allow the sale and use of medicinal Cannabis. In 2017, Peru approved a law that allows, upon registration, the medicinal Cannabis access for patients, importers, research and public entities. Also, the Peruvian government developed a system where the registered person or entity can obtain a license for researching, importing, commercializing and producing (Peru, 2019). Argentina on the other hand, issued a rule that allows patients to import Cannabis while the government is responsible for the local production (Vito, 2017). In Mexico, a reform on the General Health Law and Federal Criminal Code in 2017 authorized the Cannabis uses for medical and scientific purposes, ensuring that patients have access to pharmacological products containing THC or not (Mexico, 2017).

In the United States, the Cannabis use is not approved by the FDA, only one Cannabis-derived product is allowed, as previously mentioned, Epidiolex is a CBD purified employed for the treatment of seizures associated with Lennox-Gastaut 
syndrome or Dravet syndrome in patients with 2 years of age and older. Moreover, three others Cannabis-based compounds were approved: Marinol and Syndros (dronabinol) for therapeutic use in patients with nausea associated with cancer chemotherapy and for patients with anorexia related to weight loss due to AIDS. Another Cannabis derivative compound approved by the FDA is Cesamet (nabilone), which is indicated for nausea associated with cancer chemotherapy. These are the only Cannabis-derived products authorized by the American agency upon prescription from a licensed healthcare professional (FDA, 2020).

\section{Final Considerations}

Several studies have been demonstrated the remarkable therapeutic potential of the genus Cannabis. Thereby, the plant and its derivatives present medicinal uses in diseases such as pulmonary emphysema, asthma, intestinal constipation, some types of pain, besides Central Nervous System disorders, as epilepsy, anxiety, insomnia, neuralgia, migraine, among others. The discovery of cannabinoid receptors and endocannabinoids have further assisted in the search for new therapeutic applications for Cannabis.

Regarding the commercially available medicines, we can observe that the adverse effects of isolated cannabinoids are more pronounced and severe than natural Cannabis extracts, because isolated cannabinoids are more concentrated in comparison to the secondary metabolites found in plant. In this context, further studies are needed from natural cannabinoids for designing of safer and more effective drugs.

There are several barriers to carry out experiments and researches involving Cannabis, both in its phytochemical evaluation and in terms of its therapeutic use. Among these difficulties, there is prejudice and some countries still consider it only as an abuse drug due to its psychoactive components and thus prohibiting its cultivation. Despite these difficulties, there are already cannabinoid-like drugs playing in the treatment of many patients who showed non-responsive to several conventional therapies without positive results. All findings show that Cannabis-based drugs are a promising source for the search for new drugs for therapeutic indications still untreated.

Currently, we can see major changes in regulation in some countries with the revision of laws, which hinder the development and use of Cannabis-derived medicines due to the pressure generated by several judicial petitions to use and import of these drugs, as an alternative to conventional treatments. In Brazil, a resulting movement was the publication of Resolution RDC n ${ }^{\circ} 327 / 2019$ by ANVISA responsible for regulate the Cannabis derivative products for medicinal purposes. These actions coupled with the wide therapeutic interest aroused by these compounds have been enabling new researches involving to the plant and its compounds, which have encouraged the expansion of our Cannabis knowledge and the development of new drugs.

The plant decriminalization or even legalization in several countries worldwide has provided naturally the expansion and financial market movement around Cannabis, mainly boosting the pharmaceutical field. The prospects are great for medicinal applications, and in the near future we believe it will be able to better understand the endocannabinoid system and its physiological role in the regulation of different biochemical pathways, which is quite complex and poorly explored. Thereby, this is a promising field for designing of new drugs with novel targets in the central and peripheral nervous systems involved, for instance, with neurodegenerative disorders, as Alzheimer's, Parkinson's diseases and multiple sclerosis. However, it is essential to reduce bureaucracy in researching Cannabis, specially in countries as Brazil, where the plant and derivatives still face several obstacles for its cultivation or even the import for scientifically proven biomedical applications, making it difficult to establish safe, adequate dosage and reproducibility parameters. Finally, we believe that the studies showing the benefits of medicinal uses of Cannabis will induce the bureaucracy reduction regarding this topic, which will stimulate national development and production of Cannabis-based products, decreasing the costs for treatment with these therapeutic agents. 


\section{References}

Aizpurua-Olaizola, O., Soydaner, U., Öztürk, E., Schibano, D., Simsir, Y., Navarro, P., \& Usobiaga, A. (2016). Evolution of the cannabinoid and terpene content during the growth of Cannabis sativa plants from different chemotypes. Journal of natural products, 79(2), 324-331.

Akram, H., Mokrysz, C., \& Curran, H. V. (2019). What are the psychological effects of using synthetic cannabinoids? A systematic review. Journal of Psychopharmacology, 33(3), 271-283.

Andre, C. M., Hausman, J. F., \& Guerriero, G. (2016). Cannabis sativa: the plant of the thousand and one molecules. Frontiers in plant science, 7, 19.

ANVISA, 2017. MEVATYL®: $\quad$ tetraidrocanabinol, $\quad$ canabidiol. $2019 \quad$ Decitad http://www.anvisa.gov.br/datavisa/fila_bula/frmVisualizarBula.asp?pNuTransacao=23558192017\&pIdAnexo=10327854 .

Atwood, B. K., \& Mackie, K. (2010). CB2: a cannabinoid receptor with an identity crisis. British journal of pharmacology, 160(3), 467-479.

Barnes, M. P. (2006). Sativex®: clinical efficacy and tolerability in the treatment of symptoms of multiple sclerosis and neuropathic pain. Expert opinion on pharmacotherapy, 7(5), 607-615.

Becker, J., \& Nardin, J. M. (2011). Utilização de antieméticos no tratamento antineoplásico de pacientes oncológicos. Revista Brasileira de Farmácia Hospitalar e Serviços de Saúde, 2(3), 1-1.

Bedrocan. https://bedrocan.com/products-services/healthcare/cannabis-oil/.

Biehl, J. R., \& Burnham, E. L. (2015). Cannabis smoking in 2015: a concern for lung health?.Chest, 148(3), 596-606.

Bonn-Miller, M. O., ElSohly, M. A., Loflin, M. J., Chandra, S., \& Vandrey, R. (2018). Cannabis and cannabinoid drug development: evaluating botanical versus single molecule approaches. International Review of Psychiatry, 30(3), 277-284.

Borodovsky, J. T., Crosier, B. S., Lee, D. C., Sargent, J. D., \& Budney, A. J. (2016). Smoking, vaping, eating: is legalization impacting the way people use Cannabis?. International Journal of Drug Policy, 36, 141-147.

Carcieri, C., Tomasello, C., Simiele, M., De Nicolò, A., Avataneo, V., Canzoneri, L., \& D'Avolio, A. (2018). Cannabinoids concentration variability in Cannabis olive oil galenic preparations. Journal of Pharmacy and Pharmacology, 70(1), 143-149.

Cichewicz, D. L., \& McCarthy, E. A. (2003). Antinociceptive synergy between $\Delta 9$-tetrahydrocannabinol and opioids after oral administration. Journal of Pharmacology and Experimental Therapeutics, 304(3), 1010-1015.

Clermont-Gnamien, S., Atlani, S., Attal, N., Le Mercier, F., Guirimand, F., \& Brasseur, L. (2002). The therapeutic use of D9-tetrahydrocannabinol (dronabinol) in refractory neuropathic pain. Presse medicale (Paris, France: 1983), 31(39 Pt 1), 1840-1845.

Cranford, J. A., Bohnert, K. M., Perron, B. E., Bourque, C., \& Ilgen, M. (2016). Prevalence and correlates of "Vaping" as a route of Cannabis administration in medical Cannabis patients. Drug and alcohol dependence, 169, 41-47.

Crippa, J. A. S., Zuardi, A. W., \& Hallak, J. E. (2010). Uso terapêutico dos canabinoides em psiquiatria. Brazilian Journal of Psychiatry, 32 , 556-566.

Cunha, J. M. (1980). Carlini EA, Pereira AE, Ramos OL, Pimentel C, Gagliardi R, Sanvito WL, Lander N, Mechoulam R. Chronic administration of cannabidiol to healthy volunteers and epileptic patients. Pharmacology, 21, 175-185.

Den Boon, F. S., Chameau, P., Schaafsma-Zhao, Q., Van Aken, W., Bari, M., Oddi, S., \& Werkman, T. R. (2012). Excitability of prefrontal cortical pyramidal neurons is modulated by activation of intracellular type-2 cannabinoid receptors. Proceedings of the National Academy of Sciences, $109(9), 3534-3539$.

Devane, W. A., Dysarz, F. 3., Johnson, M. R., Melvin, L. S., \& Howlett, A. C. (1988). Determination and characterization of a cannabinoid receptor in rat brain. Molecular pharmacology, 34(5), 605-613.

De Vito, E. L. (2017). Argentina enacts first law on medical use of the Cannabis plant. History and perspectives. Medicina, 77(5), 388-393.

Di Marzo, V., \& De Petrocellis, L. (2012). Why do cannabinoid receptors have more than one endogenous ligand?. Philosophical Transactions of the Royal Society B: Biological Sciences, 367(1607), 3216-3228.

Di Marzo, V., Stella, N., \& Zimmer, A. (2015). Endocannabinoid signalling and the deteriorating brain. Nature Reviews Neuroscience, 16(1), 30-42.

Drugbank. Epidiolex: Cannabidiol. https://www.drugbank.ca/drugs/DB09061.

Drugbank. Sativex: Nabiximols. https://www.drugbank.ca/drugs/DB14011.

Eichler, M., Spinedi, L., Unfer-Grauwiler, S., Bodmer, M., Surber, C., Luedi, M., \& Drewe, J. (2012). Heat exposure of Cannabis sativa extracts affects the pharmacokinetic and metabolic profile in healthy male subjects. Planta Medica, 78(07), 686-691.

Fankhauser, M. (2002). History of Cannabis in Western medicine (pp. 37-51): The Haworth Integrative Healing Press.

Fathordoobady, F., Singh, A., Kitts, D. D., \& Pratap Singh, A. (2019). Hemp (Cannabis sativa L.) extract: Anti-Microbial properties, methods of extraction, and potential oral delivery. Food Reviews International, 35(7), 664-684.

FDA Cesamet. https://www.accessdata.fda.gov/drugsatfda_docs/label/2006/018677s011lbl.pdfa.

FDA Epidiolex®: canabidiol. https://www.accessdata.fda.gov/drugsatfda_docs/label/2018/210365lbl.pdfb. 
FDA Marinol®: dronabinol. USA: Solvay Pharmaceuticals. U.S. Food and Drug Administration (FDA). 2006. https://www.accessdata.fda.gov/drugsatfda_docs/label/2005/018651s021lbl.pdf.

Francischetti, E. A., \& Abreu, V. G. D. (2006). O sistema endocanabinóide: nova perspectiva no controle de fatores de risco cardiometabólico. Arquivos Brasileiros de Cardiologia, 87(4), 548-558.

Glass, M., Faull, R. L. M., \& Dragunow, M. (1997). Cannabinoid receptors in the human brain: a detailed anatomical and quantitative autoradiographic study in the fetal, neonatal and adult human brain. Neuroscience, 77(2), 299-318.

Gonsiorek, W., Lunn, C., Fan, X., Narula, S., Lundell, D., \& Hipkin, R. W. (2000). Endocannabinoid 2-arachidonyl glycerol is a full agonist through human type 2 cannabinoid receptor: antagonism by anandamide. Molecular pharmacology, 57(5), 1045-1050.

Grant, I., Atkinson, J. H., Gouaux, B., \& Wilsey, B. (2012). Medical marijuana: clearing away the smoke. The open neurology journal, 6, 18.

Grof, C. P. (2018). Cannabis, from plant to pill. British journal of clinical pharmacology, 84(11), 2463-2467.

Grotenhermen, F., \& Müller-Vahl, K. (2016). Medicinal uses of marijuana and cannabinoids. Critical Reviews in Plant Sciences, 35(5-6), 378-405.

Gw Pharmaceuticals, Sativex®. https://www.gwpharm.com/healthcare-professionals/sativex/>a.

Gw Pharmaceuticals, Epidiolex®. https://www.gwpharm.com/healthcare-professionals/epidiolexb.

Hazekamp, A., Ware, M. A., Muller-Vahl, K. R., Abrams, D., \& Grotenhermen, F. (2013). The medicinal use of Cannabis and cannabinoids—an international cross-sectional survey on administration forms. Journal of psychoactive drugs, 45(3), 199-210.

Howlett, A. C. (1998). The CB1Cannabinoid Receptor in the Brain. Neurobiology of disease, 5(6), 405-416.

Huestis, M. A. (2007). Human cannabinoid pharmacokinetics. Chemistry \& biodiversity, 4(8), 1770.

Hunt, C. A., \& Jones, R. T. (1980). Tolerance and disposition of tetrahydrocannabinol in man. Journal of Pharmacology and Experimental Therapeutics, 215(1), $35-44$.

Iannotti, F. A., Di Marzo, V., \& Petrosino, S. (2016). Endocannabinoids and endocannabinoid-related mediators: targets, metabolism and role in neurological disorders. Progress in lipid research, 62, 107-128.

Lanz, C., Mattsson, J., Soydaner, U., \& Brenneisen, R. (2016). Medicinal Cannabis: in vitro validation of vaporizers for the smoke-free inhalation of Cannabis. PLoS One, 11(1), e0147286.

Leghissa, A., Hildenbrand, Z. L., \& Schug, K. A. (2018). A review of methods for the chemical characterization of Cannabis natural products. Journal of separation science, 41(1), 398-415.

Lemberger, L., Crabtree, R. E., \& Rowe, H. M. (1972). 11-Hydroxy-49-tetrahydrocannabinol: pharmacology, disposition, and metabolism of a major metabolite of marihuana in man. Science, 177(4043), 62-64.

Lessa, M. A., Cavalcanti, I. L., \& Figueiredo, N. V. (2016). Derivados canabinóides e o tratamento farmacológico da dor. Revista Dor, $17(1), 47-51$.

Lewis, M. M., Yang, Y., Wasilewski, E., Clarke, H. A., \& Kotra, L. P. (2017). Chemical profiling of medical Cannabis extracts. ACS omega, 2(9), 6091-6103.

Ángeles López, G. E., Brindis, F., Cristians Niizawa, S., \& Ventura Martínez, R. (2014). Cannabis sativa L., una planta singular. Revista mexicana de ciencias farmacéuticas, 45(4), 1-6.

Lucas, C. J., Galettis, P., \& Schneider, J. (2018). The pharmacokinetics and the pharmacodynamics of cannabinoids. British journal of clinical pharmacology, 84(11), 2477-2482.

Lutz, B., Marsicano, G., Maldonado, R., \& Hillard, C. J. (2015). The endocannabinoid system in guarding against fear, anxiety and stress. Nature Reviews Neuroscience, 16(12), 705-718.

Maccarrone, M., Bab, I., Bíró, T., Cabral, G. A., Dey, S. K., Di Marzo, V., \& Zimmer, A. (2015). Endocannabinoid signaling at the periphery: 50 years after THC. Trends in pharmacological sciences, 36(5), 277-296.

MacCallum, C. A., \& Russo, E. B. (2018). Practical considerations in medical Cannabis administration and dosing. European journal of internal medicine, 49, $12-19$.

Martin, J. H., Schneider, J., Lucas, C. J., \& Galettis, P. (2018). Exogenous cannabinoid efficacy: merely a pharmacokinetic interaction?. Clinical pharmacokinetics, 57(5), 539-545.

Melo, L. A. D., \& Santos, A. D. O. (2016). O uso do Canabidiol no Brasil e o posicionamento do órgão regulador.

Mechoulam, R., \& Parker, L. A. (2013). The endocannabinoid system and the brain. Annual review of psychology, 64, 21-47.

Mexico, 'Diario Oficial de la Federación,' 19 June 2017. http://www.dof.gob.mx/nota_detalle.php?codigo=5487335\&fecha=19/06/2017

Morena, M., Patel, S., Bains, J. S., \& Hill, M. N. (2016). Neurobiological interactions between stress and the endocannabinoid system. Neuropsychopharmacology, 41(1), 80-102.

Munro, S., Thomas, K. L., \& Abu-Shaar, M. (1993). Molecular characterization of a peripheral receptor for cannabinoids. Nature, 365(6441), 61-65. 
Newmeyer, M. N., Swortwood, M. J., Andersson, M., Abulseoud, O. A., Scheidweiler, K. B., \& Huestis, M. A. (2017). Cannabis edibles: Blood and oral fluid cannabinoid pharmacokinetics and evaluation of oral fluid screening devices for predicting $\Delta 9$-tetrahydrocannabinol in blood and oral fluid following Cannabis brownie administration. Clinical chemistry, 63(3), 647-662.

Nicolussi, S., \& Gertsch, J. (2015). Endocannabinoid transport revisited. Vitamins \& Hormones, 98, 441-485.

Pain S. A potted history. Nature 2015;525:5-6.

Pamplona, F. A. (2014). Quais são e pra que servem os medicamentos à base de Cannabis. Revista da biologia, 13(1), 28-35.

Parmar, J. R., Forrest, B. D., \& Freeman, R. A. (2016). Medical marijuana patient counseling points for health care professionals based on trends in the medical uses, efficacy, and adverse effects of Cannabis-based pharmaceutical drugs. Research in Social and Administrative Pharmacy, 12(4), 638-654.

Parsons, L. H., \& Hurd, Y. L. (2015). Endocannabinoid signalling in reward and addiction. Nature Reviews Neuroscience, 16(10), 579-594.

Pertwee, R. G. (2010). Receptors and channels targeted by synthetic cannabinoid receptor agonists and antagonists. Current medicinal chemistry, 17(14), 13601381 .

Peru, 2019. Ministerio de Salud. $\quad$ Decreto $\quad$ Supremo ${ }^{\circ}$ - 2019-AS. https://cdn.www.gob.pe/uploads/document/file/297302/Decreto_Supremo_N\%C2\%BA_005-2019-SA.PDF.

Petrosino, S., \& Di Marzo, V. (2010). FAAH and MAGL inhibitors: therapeutic opportunities from regulating endocannabinoid levels. Current opinion in investigational drugs (London, England: 2000), 11(1), 51-62.

Pisanti, S., \& Bifulco, M. (2017). Modern history of medical Cannabis: from widespread use to prohibitionism and back. Trends in Pharmacological Sciences, 38(3), 195-198.

Pollastro, F., Minassi, A., \& Fresu, L. G. (2018). Cannabis phenolics and their bioactivities. Current medicinal chemistry, 25(10), 1160-1185.

Ribeiro, J. A. C. (2014). A Cannabis e suas aplicações terapêuticas (Doctoral dissertation, [sn]).

Russell, C., Rueda, S., Room, R., Tyndall, M., \& Fischer, B. (2018). Routes of administration for Cannabis use-basic prevalence and related health outcomes: A scoping review and synthesis. International Journal of Drug Policy, 52, 87-96.

Russo, E., \& Guy, G. W. (2006). A tale of two cannabinoids: the therapeutic rationale for combining tetrahydrocannabinol and cannabidiol. Medical hypotheses, 66(2), 234-246.

Russo, E. B., Jiang, H. E., Li, X., Sutton, A., Carboni, A., Del Bianco, F., \& Li, C. S. (2008). Phytochemical and genetic analyses of ancient Cannabis from Central Asia. Journal of experimental botany, 59(15), 4171-4182.

Russo, E. B. (2008). Clinical endocannabinoid deficiency (CECD). Neuroendocrinology Letters, 29(2).

Russo, E. B. (2011). Taming THC: potential Cannabis synergy and phytocannabinoid-terpenoid entourage effects. British journal of pharmacology, 163(7), 1344-1364.

Russo, E. B. (2016). Beyond Cannabis: Plants and the endocannabinoid system. Trends in Pharmacological Sciences, 37(7), 594-605.

Ryberg, E., Vu, H. K., Larsson, N., Groblewski, T., Hjorth, S., Elebring, T., \& Greasley, P. J. (2005). Identification and characterisation of a novel splice variant of the human CB1 receptor. FEBS letters, 579(1), 259-264.

Schwope, D. M., Karschner, E. L., Gorelick, D. A., \& Huestis, M. A. (2011). Identification of recent Cannabis use: whole-blood and plasma free and glucuronidated cannabinoid pharmacokinetics following controlled smoked Cannabis administration. Clinical chemistry, 57(10), 1406-1414.

Shire, D., Carillon, C., Kaghad, M., Calandra, B., Rinaldi-Carmona, M., Le Fur, G., \& Ferrara, P. (1995). An amino-terminal variant of the central cannabinoid receptor resulting from alternative splicing. Journal of Biological Chemistry, 270(8), 3726-3731.

Smerp. ACOMPLIA®. 2019. https://www.smerp.com.br/anvisa/?ac=prodSearch\&fastSearch=acomplia\#results .

Smerp. MEVATYL®. 2019. https://www.smerp.com.br/anvisa/?ac=prodSearch\&fastSearch=mevatyl\#results.

Stella, N. (2009). Endocannabinoid signaling in microglial cells. Neuropharmacology, 56, 244-253.

Mabou Tagne, A., Marino, F., Legnaro, M., Luini, A., Pacchetti, B., \& Cosentino, M. (2019). A novel Standardized Cannabis sativa L. extract and its constituent cannabidiol inhibit human polymorphonuclear leukocyte functions. International journal of molecular sciences, $20(8), 1833$.

Therapeutic Goods Administration (TGA), 2013. Australian public assessment report for nabiximols. https://www.tga.gov.au/sites/default/files/ausparnabiximols-130927.pdf.

Turu, G., \& Hunyady, L. (2009). Signal transduction of the CB1 cannabinoid receptor. Journal of molecular endocrinology, 44(2), 75-85.

U. S. Food and Drug Administration (FDA), 2020. FDA and Cannabis: Research and Drug Approval Process. https://www.fda.gov/news-events/public-healthfocus/fda-and-cannabis-research-and-drug-approval-process

Valvassori, S. S., Elias, G., de Souza, B., Petronilho, F., Dal-Pizzol, F., Kapczinski, F., \& Crippa, J. A. (2011). Effects of cannabidiol on amphetamine-induced oxidative stress generation in an animal model of mania. Journal of Psychopharmacology, 25(2), 274-280. 
Research, Society and Development, v. 10, n. 7, e58010716930, 2021

(CC BY 4.0) | ISSN 2525-3409 | DOI: http://dx.doi.org/10.33448/rsd-v10i7.16930

Wei, D., Allsop, S., Tye, K., \& Piomelli, D. (2017). Endocannabinoid signaling in the control of social behavior. Trends in neurosciences, 40(7), 385-396.

WHO, 2015. Update of Cannabis and its medical use. https://www.who.int/medicines/access/controlled-substances/6_2_cannabis_update.pdf.

Zlas, J., Stark, H., Seligman, J., Levy, R., Werker, E., Breuer, A., \& Mechoulam, R. (1993). Early medical use of Cannabis. Nature, 363(6426), $215-215$.

Zou, S., \& Kumar, U. (2018). Cannabinoid receptors and the endocannabinoid system: signaling and function in the central nervous system. International journal of molecular sciences, 19(3), 833 . 